\title{
Distribution patterns of a marsh vegetation metacommunity in relation to habitat configuration
}

\author{
Esther Sebastián-González ${ }^{1,4, *}$, José A. Molina², Mariano Paracuellos ${ }^{3}$ \\ ${ }^{1}$ Ecology Area, Department of Applied Biology, Miguel Hernández University, Elche, Spain \\ ${ }^{2}$ Department of Plant Biology II, Complutense University, 28040 Madrid, Spain \\ ${ }^{3}$ Aquatic Ecology and Aquaculture Research Group, Almería University, 04770 Adra, Almería, Spain \\ ${ }^{4}$ Present address: Departamento de Ecologia-IB, Universidade de São Paulo (USP), Rua do Matão, Travessa 14, \\ Cidade Universitária, CEP 05508-900 São Paulo, Brazil
}

\begin{abstract}
The identification of the factors behind the distribution of plant communities in patched habitats may prove useful towards better understanding how ecosystems function. Plant assemblages are especially important for wetland productivity and provide food and habitat to animals. The present study analyses the distribution of a metacommunity of helophytes and phreatophytes in a wetland complex in oder to identify the effects of habitat configuration on the colonisation process. Ponds with wide vegetated shores and a short distance to a big ( $>10$ ha) wetland, had higher species richness. The average percentage of surface covered by each species in all the wetlands correlated positively with the number of patches occupied by that species. Moreover, the community presented a nested pattern (species-poor patches were subsets of speciesrich patches), and this pattern came about by selective extinction and colonisation processes. We also detected the presence of some idiosyncratic species that did not follow nestedness. Conservation managers should attempt to maximise the vegetated shore width and to reduce the degree of isolation to enhance species richness. Furthermore, a single large and poorly isolated reserve may have the highest level of biodiversity in emergent vegetation species in this wetland complex, however, the particular ecological requirements of idiosyncratic species should also be taken into account when managing this type of community.
\end{abstract}

KEY WORDS: Colonization · Extinction $\cdot$ Nestedness $\cdot$ Wetland $\cdot$ Phreatophytes $\cdot$ Helophytes

\section{INTRODUCTION}

Disentangling the factors behind the distribution of animal and plant communities can prove useful to better understand how ecosystems function (Litchman \& Klausmeier 2008). Many of these communities are distributed in patches, where suitable habitat areas for a set of species are surrounded by a matrix of non-available habitat. Metacommunities are species assemblages in patches that are linked by dispersed multiple potentially interacting species (Leibold et al. 2004). Several variables may affect distribution patterns in metacommunities, but the spatial configuration of patches and their habitat characteristics are among the most important ones (Morin 1999). Therefore, studies on the distribution of metacommunities that account for these factors can provide relevant information for species management (see Parris 2006).

Wetlands are a clear example of patched habitats, especially in semi-arid regions. They support wet habitats in dry surroundings. Due to human activities, they are one of the most seriously threatened ecosystems in the world. One example can be found in the Mediterranean area, where natural wetlands have been reduced by 80 to $90 \%$ (Finlayson et al. 1992). Habitat loss and fragmentation have become one of the most important causes of species decline and loss, and have led to drastic changes in the struc- 
ture of plant and animal communities (Fahrig 2003, Cagnolo et al. 2006). Therefore, the landscape configuration of the resulting patchy habitats plays an important role in the distribution and abundance of species (Hernández-Stefanoni 2006). In this sense, it is important to acquire more knowledge about species distribution patterns to develop management measures for their conservation.

A common approach to studying the organisation of communities is to search for the distribution patterns and the processes causing these patterns (i.e. Barrett et al. 2010), such as the nested pattern in patchy habitats. When a community is 'nested', the species present in the poor patches are sub-samples of those present in the rich ones, and the same species tend to disappear from each patch in approximately the same order (Atmar \& Patterson 1993, Patterson \& Atmar 2000). Nestedness can be the outcome of different processes, the commonest being selective extinction, selective colonisation, presence of a nested habitat and passive sampling (Lomolino 1996, Wethered \& Lawes 2005). Moreover, the nestedness theory has also been applied in conservation policies as it can be used in reserve design and to identify species of special interest (Fleishman et al. 2007).

When considering the usual patchy configuration of wetlands, not only because of their natural origin but also as a result of habitat fragmentation, the application of insularity models for marsh vegetation metacommunities might prove suitable (Pennings \& Silliman 2005, Kunza \& Pennings 2008). Understanding the repercussions of habitat patchiness on the distribution of these assemblages gains importance because they play multiple roles in the functioning of wetlands. Plant communities play a crucial role in fixing energy, supplying oxygen, and contribute to habitat structure (Cronk \& Fennessy 2001). Furthermore, many animal species, some of which are globally threatened, depend on wetland emergent vegetation for their habitat (Mitsch \& Gosselink 1993, Hawke \& José 1996).

The present study analyses the distribution of vegetation in a wetland complex in order to identify how habitat configuration determines the distribution of plant species. For this purpose, 2 processes were studied:

(1) The importance of different environmental variables as predictors of species richness and community composition in relation to habitat configuration. We predicted that small, isolated patches would have a smaller number of species than large, clumped patches. We also expected some environmental vari- ables to be important for the presence of marsh vegetation species.

(2) The effect of plant species coverage on species' ability to colonise patches. We predicted that the number of patches occupied by each species would correlate positively with the plant coverage of the community. We expected those plants with lowdemand ecological requirements and high dispersal abilities to be more widespread. For instance, the species loss pattern would be ordered depending on the occurrence of each species (the 'nested' pattern). Moreover, we also studied the possible causes behind the nested pattern, and the implications for those species that do not follow that pattern (known as idiosyncratic species).

The results obtained in this study can be used in making decisions about how to maintain or maximise the species diversity of helophytes and phreatophytes in patched habitats, which can also be applied to their conservation and management.

\section{MATERIALS AND METHODS}

\section{Study area}

The study was carried out in a wetland complex of 22 marshes no further apart from each other than $30 \mathrm{~km}$ in the Baja Alpujarra (Southeast Iberian littoral, Almería, Spain; $36^{\circ} 48^{\prime} \mathrm{N}, 2^{\circ} 42^{\prime} \mathrm{W}$ ), where there are no similar wetlands for at least a distance of $50 \mathrm{~km}$. Each marsh consisted of a unique patch. The marshes were situated in a flat area (0 to $50 \mathrm{~m}$ a.s.1.) covered mainly by a matrix of greenhouses (Fig. 1) used to grow produce for human consumption (i.e. tomatoes, watermelons, paprika, cucumbers). The greenhouses are in general completely closed and the plants grown inside never appeared in the surveyed wetlands, and all the surveys were performed outside these greenhouses. Human action has an effect on the wetlands, but previous studies in the area have to date suggested that variables other than human influence are affecting the structure of the animal communities the most (Paracuellos \& Telleria 2004, Paracuellos 2006a,b,c, 2008). Therefore, we believe our results are also applicable to other similar areas with or without the surrounding greenhouses. Rainfall in the area is scarce (annual range: 200 to $350 \mathrm{~mm}$ ) and temperatures are mild (mean annual temperature range: 17 to $19^{\circ} \mathrm{C}$, minimum average temperature: $>6^{\circ} \mathrm{C}$, annual fluctuation in temperature: $\sim 13^{\circ} \mathrm{C}$ ), these being typical of the Mediterranean environment (Capel 1990). The few unculti- 

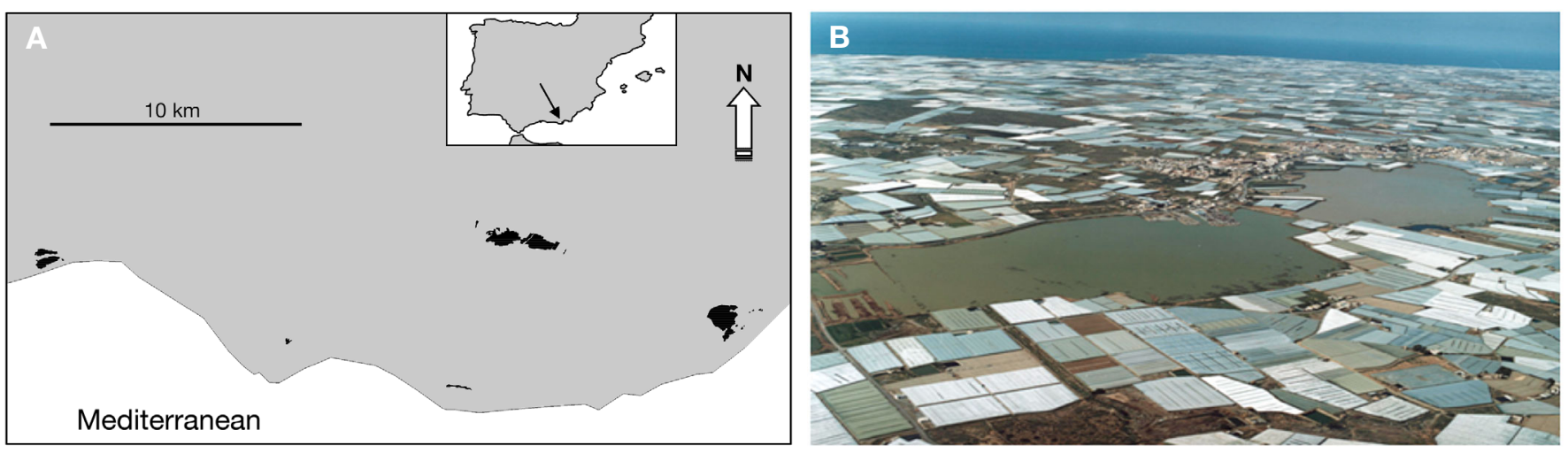

Fig. 1. (A) Geographical distribution of the study marshes (black areas). (B) Aerial photograph of a study wetland complex as islands of water in a sea of plastic (photo: Técnicas Fotográficas)

vated spaces available are usually colonised by natural Mediterranean shrubs (Pistacia lentiscus, Rosmarinus officinalis, Thymus spp.) (Mota et al. 1996). These wetlands are of a diverse origin since some are related to river deltas $(\mathrm{N}=4)$, while others are abandoned saltpans $(\mathrm{N}=16)$ or coastal salt marshes of an endorheic origin $(\mathrm{N}=2)$. Several of these wetlands are legally protected and only management practices relating to conservation purposes are allowed. We included all the existing wetlands in the study area.

These wetlands are true islands for marshdependent species. They have open, permanent and deep, slightly salty water, which is often surrounded by a ring of emergent vegetation, composed mainly of helophytes and phreatophytes, which are dispersed mainly by wind and water. Helophytes occupy the lower marsh, while phreatophytes grow in the higher marsh (Casas et al. 2003, Giménez et al. 2003). The dominant species are Phragmites australis and Tamarix canariensis with 69 and $25 \%$ of coverage, respectively.

\section{Field data}

In each independent marsh, 14 variables were sampled (Table 1). As the marsh limits were well delimited, we considered that their separation (a distance of at least $20 \mathrm{~m}$ from the nearest marsh) was enough to consider them independent communities within the metacommunity. The studied variables are normally used in studies that assess relationships between marsh plants and environmental and spatial variables. The spatial variables (variables 1 to 8 in Table 1) were calculated using the ArcView GIS 3.1 software (Environmental Systems Research Institute 1992-1998) based on 1:2000 aerial photographs taken in 1998. The age of the wetlands in their pre- sent ecological state and their origin were estimated using bibliography, historical documentation, authors' own data, personal communications and aerial photographs. In the spring of 1997-1998 (April to May), the identity and abundance of emergent vegetation species were sampled in each vegetation patch. The presence and coverage occupied by each species (9 in total: Tamarix canariensis, Phragmites australis, Typha domingensis, T. latifolia, Juncus acutus, J. maritimus, Cladium mariscus, Bolboschoenus maritimus and Schoenoplectus litoralis) were visually estimated within randomly chosen circles with a $25 \mathrm{~m}$ radius ( 1 to 20 circles per patch, depending on patch size). Low plant coverage facilitated visual estimations. Observations were made from one point. When the identity of a species was not clear, we subsequently verified the genus and species by getting closer to the individual plant. With this information, the following plant and patch characteristics were taken into account: (1) the number of species in each patch (sum of all the species found in the samples taken in each patch), (2) species abundance (the average value of the plant species coverage in marsh patches $>10$ ha, where insularity had to have a lower effect), and (3) the occupation frequency of marsh patches at species level.

\section{Statistical analyses}

To study the relationships among species and the spatial and environmental variables, ordination analyses were performed using CANOCO for Windows 4.1. This program enables partial analyses in which the influence of particular variables (termed 'covariables') is eliminated before the influence of the variables of interest (termed 'environmental variables') 
Table 1. Environmental variables measured in the different marshes and sampling method used. *Variables logarithmically modified for the analyses

\begin{tabular}{|c|c|}
\hline Variable & Method of sampling \\
\hline 1. Total surface & $\begin{array}{l}\text { Open water surface }+ \text { emergent vegetation surface delimited by } \\
\text { means of digital planimetry }\end{array}$ \\
\hline 2. Surface covered by emergent vegetation & Digital planimetry \\
\hline 3. Percentage of shore occupied by emergent vegetation & Digital planimetry \\
\hline 4. Width of shore occupied by emergent vegetation & Digital planimetry \\
\hline 5. Distance to the nearest wetland ${ }^{*}$ & Digital planimetry \\
\hline 6. Distance to the nearest wetland $>1 \mathrm{ha}^{*}$ & Digital planimetry \\
\hline 7. Distance to the nearest wetland $>10$ ha $^{*}$ & Digital planimetry \\
\hline 8. Surface covered by wetlands in a $5 \mathrm{~km}$ radius & Digital planimetry \\
\hline 9. Maximum water depth & $\begin{array}{l}\text { Mean values of various depth records measured about the center } \\
\text { of the marsh at the moments of maximum flood during February } \\
1998\end{array}$ \\
\hline 10. Minimum annual salinity & $\begin{array}{l}\text { Digital multiparametric probe at the moments of maximum flood } \\
\text { during February } 1998\end{array}$ \\
\hline 11. Minimum concentration of total phosphorus in water & $\begin{array}{l}\text { Colorimetry at the moments of maximum flood during February } \\
1998\end{array}$ \\
\hline 12. Average height of the emergent vegetation & $\begin{array}{l}\text { Values visually estimated within circles of } 25 \mathrm{~m} \text { radius randomly } \\
\text { chosen ( } 1 \text { to } 20 \text { per patch), during the } 1997-1998 \text { spring (Apr-May) }\end{array}$ \\
\hline 13. Age in its present ecological state & $\begin{array}{l}\text { Bibliography, historical documentation, own data, pers. comm. and } \\
\text { aerial photographs taken successively throughout the time. } \\
\text { It refers to the state in the moment of the surveys }\end{array}$ \\
\hline 14. Pond origin & Bibliography, historical documentation, own data and pers. comm. \\
\hline
\end{tabular}

is tested. Ordination analyses are a descriptive/ exploratory technique designed to analyse multiway tables containing some measure of correspondence between rows and columns (Legendre \& Legendre 1998). Ordination analyses attribute scores to both species and the environmental and spatial variables so that the correlation between their scores is maximal given the best 'correspondence' between species and variables (Prodon 1992). Redundancy analyses (RDA) were selected from the different ordination procedures. RDA order species using axes that are linear combinations of the external variables, in such a way that the relationship between the species and these variables can be clearly seen. We included the UTM coordinates of the patches as covariables to account for spatial correlation. Significance was tested by the distribution-free Monte Carlo test (1000 permutations), in which the distribution of the test statistics under the null hypothesis is generated by random permutations of cases in the environmental data (Ter Braak \& Šmilauer 1998). Multicollinearity was assessed by inter-variables correlation. Only one variable (the average percentage of surface covered by a species in the wetlands $>10$ ) was not included in the analyses because of its high correlation with the other variables (see 'Results').
To assess the existence of a nested pattern in community distribution, we constructed a matrix where each row and each column corresponded to a species and to a wetland, respectively. The matrix was reorganised to maximise nestedness in such a way that presences were packed in the upper left triangle of the matrix. We used the ANINHADO software (Guimarães \& Guimarães 2006). This program uses a metric called matrix temperature $(T)$, which is a measure of the disorder ranging from 0 (perfectly nested) to $100^{\circ}$ (random). Similar results were obtained using the NODF (acronym for nestedness metric based on overlap and decreasing fill) metric (Almeida-Neto et al. 2008). The NODF metric quantifies 2 major properties for nestedness: whether marginal totals differ among columns and/or among rows, and whether the presences in less filled columns and rows coincide with those found in the more-filled columns and rows respectively (Almeida-Neto et al. 2008). The $T$ of the matrix was calculated and compared with the $T \mathrm{~s}$ of 2 null models. ANINHADO first uses a null model based on a random distribution of the presences assigned to any cell within the matrix, and then a second null model that assumedly controls the effects of passive sampling (Jonsson 2001). In our case, the presence of species $i$ in patch $j$ in the second null 
model was the arithmetic mean of the presence probability of patch $j$ (the proportion of presences in row $j$ ) and species $i$ (the proportion of presences in column $i$ ). We calculated $T$ of 1000 matrices of all the null models using Monte Carlo simulations. We then compared $T$ of our matrix with the distribution of the simulated $T \mathrm{~s}$ to test the significance of nestedness. When $T$ in the observed matrix fell within the range of variation of any of the null models, the pattern was not considered nested. Moreover, the species that deviated from perfect nestedness were identified by a peak $T$ and were termed as idiosyncratic. Therefore, a species was considered idiosyncratic if its $T$ was higher than the system's T (Atmar \& Patterson 1993).

We correlated the rank order of the wetlands in the final nested matrix to all the studied environmental and spatial variables to identify the possible causes of the pattern (Mc Abendroth et al. 2005, Heino et al. 2009). Spearman's rank $\left(r_{S}\right)$ and Pearson ( $\left.r\right)$ tests were employed in the correlations between variables according to the nature of the data using the SPSS 20.0 software (SPSS 2011). A significant correlation suggests that a community is packed in a predictable order due to the influence of the given variable. Statistical significance was set at $\alpha=0.05$ for all the analyses.

\section{RESULTS}

The Monte Carlo permutation test provided strong evidence of a correlation between presence of marsh species and 2 external variables: distance to the nearest wetland $>10$ ha in size $(F=4.00, \mathrm{p}=0.006)$ and width of the pond's vegetated shore $(F=2.15, \mathrm{p}=$ 0.05 ). The ordination plot illustrated that most species benefited from an increased vegetated shore width and from a shorter distance to another big wetland (Fig. 2). The effect of both variables was especially important for Typha domingensis and T. latifolia, while the effect for Phragmites australis was particularly low. The total observed variance of the first canonical axis was $69.6 \%$.

Moreover, the average percentage of surface covered by a species in the wetlands $>10$ ha was related to the number of patches occupied by that species in the wetland complex $(r=0.77, p=0.01)$, and was excluded from the model.

The distribution of the species in the wetland complex presented a nested pattern and the order of species loss in the vegetation patches was not random (matrix fulfillment $=47.4 \%$, observed matrix $T=9.1^{\circ}$; the entire estimated matrix $T \mathrm{~s}$ differed significantly

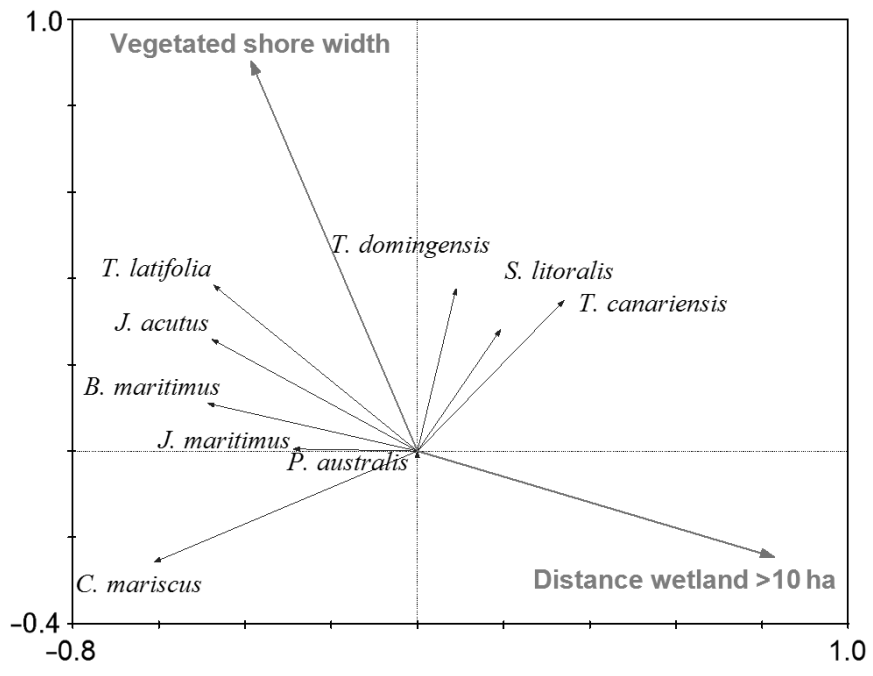

Fig. 2. Tamarix canariensis, Phragmites australis, Typha domingensis, T. latifolia, Juncus acutus, J. maritimus, Cladium mariscus, Bolboschoenus maritimus and Schoenoplectus litoralis. Redundancy analyses (RDA) ordination biplot of the marsh metacommunity. Species and environmental variables are represented by arrows that indicate the direction in which the variables are increasing. Longer arrows: stronger relationships between variables. Lines: plant species (black) and descriptive variables (grey)

from the observed matrix, $\mathrm{p}<0.001$ in null models I and II). The rank order of patches determined by the packed matrix correlated with the total surface $\left(\mathrm{r}_{\mathrm{S}}=-0.54, \mathrm{p}=0.01\right)$, with the surface covered by emergent vegetation $\left(\mathrm{r}_{\mathrm{S}}=-0.66, \mathrm{p}=0.001\right)$, and with the distance to the closest $\left(>1\right.$ ha) patch $\left(\mathrm{r}_{\mathrm{S}}=0.44, \mathrm{p}=\right.$ $0.04)$. Moreover, 5 of the studied species were idiosyncratic (Table 2): Tamarix canariensis, Schoenoplectus litoralis, Cladium mariscus, Juncus maritimus and Typha latifolia. These species had higher Ts than the $T$ of the system and they did not follow a nested pattern. Besides, most species only presented mildly high Ts compared with the system's $T$, and only 1 of them (C. mariscus) was much higher. On the other hand, both $J$. acutus and Bolboschoenus maritimus would be the first species to disappear through disturbance because they had low $T$ and low coverage.

\section{DISCUSSION}

If we consider that the plant metacommunity in this study was mainly influenced by distance to the nearest wetland ( $>10 \mathrm{ha})$, our first prediction is partially supported by the field data. In general, we can state that the plant species composition in this wetland complex might be determined by a measure of the 
Table 2. Presence (indicated by ' $x$ ') of the different emergent vegetation species in each marsh of the maximally packed matrix of distribution of helophytes and phreatophytes of the wetland complex. We indicate total surface, surface covered by emergent vegetation, and number of species for each wetland. We also indicate average coverage in patches $>10$ ha, number of occupied patches and Temperature $(T)$ in the packed matrix for each species. ${ }^{*}$ Idiosyncratic species with $T$ higher than $T$ of the system $\left(9.1^{\circ}\right)$

\begin{tabular}{|c|c|c|c|c|c|c|c|c|c|c|c|}
\hline $\begin{array}{l}\text { Total } \\
\text { surface } \\
\text { (ha) }\end{array}$ & $\begin{array}{c}\text { Veg. } \\
\text { surface } \\
\text { (ha) }\end{array}$ & $\begin{array}{c}\text { No. of } \\
\text { species }\end{array}$ & $\begin{array}{c}\text { Phrag- } \\
\text { mites } \\
\text { australis }\end{array}$ & $\begin{array}{c}\text { Tamarix } \\
\text { Canari- } \\
\text { ensis }\end{array}$ & $\begin{array}{c}\text { Typha } \\
\text { doming- } \\
\text { ensis }\end{array}$ & $\begin{array}{c}\text { Juncus } \\
\text { acutus }\end{array}$ & $\begin{array}{c}\text { Juncus } \\
\text { mari- } \\
\text { timus }\end{array}$ & $\begin{array}{c}\text { Bolbo- } \\
\text { schoenus } \\
\text { maritimus }\end{array}$ & $\begin{array}{l}\text { Cladium } \\
\text { mariscus }\end{array}$ & $\begin{array}{c}\text { Schoeno- } \\
\text { plectus } \\
\text { litoralis }\end{array}$ & $\begin{array}{c}\text { Typha } \\
\text { latifolia }\end{array}$ \\
\hline 14.93 & 7.74 & 8 & $\mathrm{x}$ & $\mathrm{x}$ & $\mathrm{x}$ & $\mathrm{x}$ & $\mathrm{x}$ & $\mathrm{x}$ & $\mathrm{x}$ & & $\mathrm{x}$ \\
\hline 31.71 & 6.68 & 7 & $\mathrm{x}$ & $\mathrm{x}$ & $\mathrm{x}$ & $\mathrm{x}$ & $\mathrm{x}$ & $\mathrm{x}$ & $\mathrm{x}$ & & \\
\hline 1.05 & 0.43 & 6 & $\mathrm{x}$ & $\mathrm{x}$ & $\mathrm{x}$ & $\mathrm{x}$ & & $\mathrm{x}$ & & & $\mathrm{x}$ \\
\hline 49.73 & 27.77 & 6 & $\mathrm{x}$ & $\mathrm{x}$ & $\mathrm{x}$ & $\mathrm{x}$ & $\mathrm{x}$ & & & $\mathrm{x}$ & \\
\hline 0.57 & 0.36 & 6 & $\mathrm{x}$ & $\mathrm{x}$ & $\mathrm{x}$ & $\mathrm{x}$ & & & $\mathrm{x}$ & $\mathrm{x}$ & \\
\hline 0.47 & 0.25 & 6 & $\mathrm{x}$ & & $\mathrm{x}$ & $\mathrm{x}$ & $\mathrm{x}$ & $\mathrm{x}$ & $\mathrm{x}$ & & \\
\hline 1.98 & 1 & 6 & $\mathrm{x}$ & $\mathrm{x}$ & $\mathrm{x}$ & $\mathrm{x}$ & $\mathrm{x}$ & $\mathrm{x}$ & & & \\
\hline 7.75 & 7.74 & 5 & $x$ & $\mathrm{x}$ & & $\mathrm{x}$ & $\mathrm{x}$ & & $\mathrm{x}$ & & \\
\hline 0.57 & 0.56 & 5 & $\mathrm{x}$ & $\mathrm{x}$ & $\mathrm{x}$ & & $\mathrm{x}$ & $\mathrm{x}$ & & & \\
\hline 88.57 & 16.45 & 5 & $\mathrm{x}$ & $\mathrm{x}$ & $\mathrm{x}$ & $\mathrm{x}$ & $\mathrm{x}$ & & & & \\
\hline 2.89 & 1.66 & 5 & $\mathrm{x}$ & $\mathrm{x}$ & $\mathrm{x}$ & $\mathrm{x}$ & $\mathrm{x}$ & & & & \\
\hline 59.52 & 6.43 & 4 & $\mathrm{x}$ & $\mathrm{x}$ & $\mathrm{x}$ & & & & & $\mathrm{x}$ & \\
\hline 4.69 & 2.14 & 4 & $\mathrm{x}$ & $\mathrm{x}$ & $\mathrm{x}$ & & & & & $\mathrm{x}$ & \\
\hline 1.59 & 1.24 & 4 & $\mathrm{x}$ & $\mathrm{x}$ & & $\mathrm{x}$ & $\mathrm{x}$ & & & & \\
\hline 0.52 & 0.06 & 3 & $\mathrm{x}$ & $\mathrm{x}$ & $\mathrm{x}$ & & & & & & \\
\hline 9.12 & 1.35 & 3 & $\mathrm{x}$ & $\mathrm{x}$ & $\mathrm{x}$ & & & & & & \\
\hline 1.5 & 0.5 & 3 & $\mathrm{x}$ & $\mathrm{x}$ & $\mathrm{x}$ & & & & & & \\
\hline 0.83 & 0.3 & 2 & $\mathrm{x}$ & $\mathrm{x}$ & & & & & & & \\
\hline 0.4 & 0.05 & 2 & $\mathrm{x}$ & $\mathrm{x}$ & & & & & & & \\
\hline 0.1 & 0.05 & 2 & $\mathrm{x}$ & $\mathrm{x}$ & & & & & & & \\
\hline 0.8 & 0.05 & 1 & $\mathrm{x}$ & & & & & & & & \\
\hline 0.2 & 0.05 & 1 & $\mathrm{x}$ & & & & & & & & \\
\hline \multicolumn{3}{|c|}{ Helophyte } & $\mathrm{x}$ & & $\mathrm{x}$ & & & $\mathrm{x}$ & $\mathrm{x}$ & $\mathrm{x}$ & $\mathrm{x}$ \\
\hline \multicolumn{3}{|c|}{ Average coverage >10 ha (\%) } & 69.32 & 24.9 & 2.3 & $<1$ & $<1$ & $<1$ & 1.67 & $<1$ & $<1$ \\
\hline \multicolumn{3}{|c|}{ No. occupied patches } & 22 & 19 & 15 & 11 & 10 & 6 & 5 & 4 & 2 \\
\hline \multicolumn{3}{|c|}{ Species $T\left(^{\circ}\right)$} & 0.00 & $10.05^{*}$ & 4.64 & 0.60 & $11.10^{*}$ & 4.09 & $27.58^{*}$ & $12.57^{*}$ & $11.32^{*}$ \\
\hline
\end{tabular}

degree of patch isolation. Several studies have confirmed the importance of patch area and degree of isolation to explain species abundance and richness in habitat patches (Petit et al. 2004, Sánchez-Zapata et al. 2005, Cagnolo et al. 2006, Sebastián-González et al. 2010). Indeed, area is also important because the distance to small patches was not selected as an explanatory variable. Patches $>10$ ha tend to have more surface covered by vegetation and higher species richness than smaller patches (Mann-Whitney $U$-test, both $\mathrm{p}<0.03)$, and can function as a source of seeds in the metacommunity complex (Mouquet \& Loreau 2003). Furthermore, none of the variables related to habitat quality (such as salinity or phosphorus concentration) influenced the metacommunity. This is probably because there were no marked variations between ponds in the values of these variables.

Plant coverage was an important predictor of a species' ability to occupy a patch (the interspecific occupancy-abundance relationship: reviewed by
Gaston et al. 1997, 2000). Therefore, the species covering higher percentages of wetland surface, such as Phragmites australis, Tamarix canariensis and Typha domingensis, also occupied a larger number of patches. On the other hand, the scarcer species occupied only a small part of the marshes, which was the case of Bolboschoenus maritimus, Cladium mariscus, Schoenoplectus litoralis and Typha latifolia.

We expected those plants with wider ecological amplitude and more diverse dispersal modes to be more geographically widespread. This evaluation was reinforced by the species' individual characteristics. Phragmites australis is the most widespread species in the area, and it is also distributed within a pond in many of the ecological zones created by the water level, although its optimum occupation is the intermediate zone (Coops \& Van der Velde 1995). P. australis is dispersed by wind and water, thus implying short- and long-distance vegetative and seed propagules dispersal (Fér \& Hroudová 2009). More- 
over, P. australis presents high phenotypic and genotypic variations in relation to environmental factors such as climate, hydrology and salinity (Clevering \& Lissner 1999). Tamarix canariensis can spread not only sexually by numerous tiny seeds that are dispersed by wind or water, but also vegetatively by adventitious roots or submerged stems (Merkel \& Hopkins 1957, Brotherson \& Field 1987). This species displays a pioneer strategy that benefits from dry seasons through its establishment on the margins of wetlands (Serrano et al. 2008). Helophytes are dominant in swamp vegetation and show marked local expansion due to rhizome spread and clonal growth, although hydrochory appears to be their main mode of dispersal (Grelsson \& Nilsson 1991). Nevertheless, dispersal by air may be relevant for the plumed propagules in Typha spp., which confer them easy long-distance dispersal.

Conversely, Bolboschoenus maritimus, Schoenoplectus litoralis and Cladium mariscus produce fewer and larger fruits that are adapted to dispersal by water (Hroudová et al. 1997, Castroviejo 2008, Luceño \& Jiménez Mejias 2008), and whose long-distance dispersal probably depends on transport by seed-consuming birds (De Vlaming \& Proctor 1968). Juncus maritimus and $J$. acutus emerge respectively in the wetter and drier parts of high saltmarshes (Molina et al. 2003). These plants have reduced dispersal ability if compared to Tamarix canariensis because they produce small unplumed seeds that cannot be dispersed by wind. The wider ecological amplitude and dispersal modes of Phragmites australis, T. canariensis and Typha domingensis could, therefore explain their broad extension in our wetlands, in addition to their abundance.

The nested pattern found in the species' loss order in vegetation patches reveals that this order was, at least partially, predictable (Atmar \& Patterson 1993). Assemblages of organisms with strong dispersal abilities, as in the studied species, may exhibit strong nested patterns of distribution (Cook \& Quinn 1995). This pattern could have come about through selective colonisation and extinction because both area (both total surface and the surface covered by emergent vegetation) and isolation (distance to the closest patch $>1$ ha) correlated with the rank species order in the packed matrix. Therefore, we can state that large yet less isolated vegetation patches might hold all the species present in small, isolated patches (as in Lomolino 1996, Schouten et al. 2007). Of the other 2 more common causes of the pattern encountered, one was controlled by use of different null models (passive sampling; see Jonsson 2001), while the other was the existence of a nested habitat (Wethered \& Lawes 2005). The studied wetlands can be related to stratification in water depth and are structured as a central deep area surrounded by a gradient of concentric rings with progressively shallower water. This implies that when wetlands become smaller in size, there is generally a nested order in loss of habitat linked to zonation from deeper to shallower waters. Thus, deeper areas are lacking in small wetlands (see Paracuellos 2006a for a similar approach with waterbirds). Nevertheless, the present study refers only to emergent vegetation, usually located surrounding the open waters in this ecological zonation. The distribution of this vegetation can only be influenced by the existence of a nested habitat if total loss of the open water zone in any of the wetlands has previously taken place. As all the marshes retained some central open water, the nestedness found there does not seem to be caused by the existence of a nested habitat. It is important to note that nested habitats can also be generated by other abiotic habitat characteristics not included in this study, such as sediment oxygenation or maximum salinity, and further research is required to clarify this.

Idiosyncratic species are those species that do not follow the nested pattern (Patterson et al. 1996). When analysing nestedness in a metacommunity, idiosyncratic species are easily identified because their behaviour differs from that of the other species. They tend to be absent from species-rich sites and often appear in poor patches. Most of these species display this behaviour due to stringent ecological range requirements, which are only met in certain marshes independently of the other environmental variables of vegetation patches, such as surface or isolation. This may be certainly true for Cladium mariscus, Schoenoplectus litoralis and Typha latifolia, which are normally more affected by water eutrophication and soil salinisation than other helophytes with which they compete for resources (Duarte et al. 1990, Alvarez-Cobelas et al. 2001, Tanaka et al. 2004). Then, their presence in a patch may be restricted to those wetlands with low eutrophication levels and low salinity, even if these wetlands are not species-rich. Furthermore, the idiosyncratic behaviour of phreatophytes Tamarix canariensis and Juncus maritimus can be explained by the lack of their specific spatial niche in some small marshes or marshes with steep margins, and by the dynamics in vegetation succession, which occurs when grazing ceases, e.g. J. maritimus, thus provoking its disappearance (Bakker et al. 2009). Moreover, T. canarien- 
sis woodlands are the late successional stage of semiarid Mediterranean wetlands (Alcaraz et al. 1989).

The results of this study indicate that the degree of isolation and, indirectly, the size of wetlands, are important variables to describe the distribution of helophytes and phreophytes in the study system. From a general viewpoint, semi-arid wetlands with a low degree of isolation might normally contain the majority of emergent plant species' biodiversity. This is supported by the RDA and by the identification of the causes of the nested pattern. Therefore, it is necessary to pay special attention to more clumped, larger patches to guarantee the presence of a larger number of species. Moreover, the appearance of idiosyncratic species is principally related to their specific habitat needs rather than to increased patch surface. Consequently, in order to contribute to the global preservation of marsh-plant diversity, the conservation or restoration of a maximum number of wetlands should be a priority, as this favours habitat heterogeneity and the persistence of idiosyncratic species. However, small patches should not be forgotten as they may act as connectors or steppingstones for many species.

Acknowledgements. E.S.-G. benefited from a FPU grant from the Ministry of Education and a FAPESP grant. F. Botella and J. A. Sánchez-Zapata provided valuable comments on an earlier manuscript draft. K. Alexander kindly improved English usage.

\section{LITERATURE CITED}

Alcaraz F, Díaz TE, Rivas Martínez S, Sánchez-Gómez P (1989) Datos sobre la vegetación del sureste de España: Provincia Biogeográfica Murciano-Almeriense. Itinera Geobotanica 2:5-133

Almeida-Neto M, Guimarães P, Guimarães PR Jr, Loyola RD, Ulrich W (2008) A consistent metric for nestedness analysis in ecological systems: reconciling concept and measurement. Oikos 117:1227-1239

Alvarez-Cobelas M, Cirujano S, Sánchez-Carrillo S (2001) Hydrological and botanical man-made changes in the Spanish wetland of Las Tablas de Daimiel. Biol Conserv 97:89-98

Atmar W, Patterson BD (1993) The measure of order and disorder in the distribution of species in fragmented habitat. Oecologia 96:373-382

Bakker JP, Dries PJK, Stahl J (2009) Community ecology and management of salt marshes. In: Verhoef HA, Morin PJ (eds) Community ecology processes, models, and applications. Oxford University Press, Oxford

Barrett K, Helms BS, Guyer C, Schoonover JE (2010) Linking process to pattern: causes of stream-breeding amphibian decline in urbanized watersheds. Biol Conserv 143:1998-2005

Brotherson JD, Field D (1987) Tamarix: impacts of a successful weed. Rangelands 3:110-112
Cagnolo L, Cabid M, Valladares G (2006) Plant species richness in the Chaco Serrano Woodland from central Argentina: ecological traits and habitat fragmentation effects. Biol Conserv 132:510-519

Capel JJ (1990) Climatología de Almería. Cuadernos monográficos 7. Instituto de Estudios Almerienses (Diputación Provincial de Almería), Almería

Casas JJ, Calvache F, Delgado S, García-Mayoral J and others (2003) Inventario abierto de los humedales de la región semiárida almeriense: consideraciones sobre su tipificación. In: Paracuellos M (ed) Ecología, manejo y conservación de los humedales. Colección Actas 49, Instituto de Estudios Almerienses (Diputación de Almería), Almería

Castroviejo S (2008) Cladium P Browne. In: Castroviejo S, Luceño M, Galán A, Jiménez Mejías $P$, Cabezas $F$, Medina L (eds) Flora iberica, Vol 18. CSIC, Madrid p 102-104

Clevering OA, Lissner J (1999) Taxonomy, chromosome numbers, clonal diversity and population dynamics of Phragmites australis. Aquat Bot 64:185-208

> Cook R, Quinn JF (1995) The influence of colonization in nested species subset. Oecologia 102:413-424

Coops H, van der Velde G (1995) Seed dispersal, germination and seedling growth of six helophyte species in relation to water level zonation. Freshw Biol 34:13-20

Cronk J, Fennessy M (2001) Wetland plants: biology and ecology. Lewis Publishers, Boca Raton, FL

> De Vlaming V, Proctor VW (1968) Dispersal of aquatic organisms: viability of seeds recovered from the droppings of captive killdeer and mallard ducks. Am J Bot 55: 20-26

Duarte C, Montes C, Agustí S, Martino P, Bernués M, Kalff J (1990) Biomasa de macrófitos acuáticos en la marisma del Parque Nacional de Doñana (SW España): importancia y factores ambientales que controlan su distribución. Limnetica 6:1-12

> Fahrig L (2003) Effects of habitat fragmentation on biodiversity. Annu Rev Ecol Syst 34:487-515

> Fér T, Hroudová Z (2009) Genetic diversity and dispersal of Phragmites australis in a small river system. Aquat Bot 90:165-171

Finlayson CM, Hollis GE, Davis TJ (1992) Managing Mediterranean wetlands and their birds. Int Waterfowl and Wetlands Res Bureau Spec Publ 20, Slimbridge

- Fleishman E, Donnelly R, Fay JP, Reeves R (2007) Applications of nestedness analyses to biodiversity conservation in developing landscapes. Landsc Urban Plan 81: 271-281

Gaston KJ, Blackburn TM, Lawton JH (1997) Interspecific abundance-range size relationships: an appraisal of mechanisms. J Anim Ecol 66:579-601

Gaston KJ, Blackburn TM, Greenwoods JJD, Gregory RD, Quinn RM, Lawton JH (2000) Abundance-occupancy relationships. J Appl Ecol 37:39-59

Giménez E, Navarro J, Oña JA, Gómez Mercado F (2003) Paraje Natural Punta Entinas-Sabinar (Almería). Flora, vegetación y ornitofauna. Monografías Ciencia y Tecnología 22, Servicio de Publicaciones (Universidad de Almería), Almería

> Grelsson G, Nilsson C (1991) Vegetation and seed-bank relationships on a lakeshore. Freshw Biol 26:199-207

> Guimarães PR Jr, Guimarães P (2006) Improving the analyses of nestedness for large sets of matrices. Environ Model Softw 21:1512-1513 
Hawke CJ, José PV (1996) Reedbed management for commercial and wildlife interests. RSPB Sandy

> Heino J, Mykrä H, Mouotka T (2009) Temporal variability of nestedness and idiosyncratic species in stream insect assemblages. Divers Distrib 15:198-206

Hernández-Stefanoni JL (2006) The role of landscape patterns of habitat types on plant species diversity of a tropical forest in Mexico. Biodivers Conserv 15:1441-1457

Hroudová Z, Moravcová L, Zákravský P (1997) Effect of anatomical structure on the buoyancy of achenes of two subspecies of Bolboschoenus maritimus. Folia Geobot Phytotaxon 32:377-390

> Jonsson BG (2001) A null model for randomization tests of nestedness in species assemblages. Oecologia 127: 309-313

Kunza AE, Pennings SC (2008) Patterns of plant diversity in Georgia and Texas salt marshes. Estuaries Coasts 31: 673-681

Legendre P, Legendre L (1998) Numerical ecology. Elsevier, Amsterdam

Leibold MA, Holyoak M, Mouquet M, Amarasekare P and others (2004) The metacommunity concept: a framework for multi-scale community ecology. Ecol Lett 7:601-613

Litchman E, Klausmeier CA (2008) Trait-based community ecology of phytoplankton. Annu Rev Ecol Evol Syst 39: 615-639

Lomolino MV (1996) Investigating causality of nestedness of insular communities: selective immigrations or extinctions? J Biogeogr 23:699-703

Luceño M, Jiménez Mejias P (2008) Schoenoplectus (Rchb) Palla. In: Castroviejo S, Luceño M, Galán A, Jiménez Mejías P, Cabezas F, Medina L (eds) Flora iberica, Vol 18. CSIC, Madrid, p 42-59

McAbendroth L, Foggo A, Rundle SD, Bilton DT (2005) Unravelling nestedness and spatial pattern in pond assemblages. J Anim Ecol 74:41-49

Merkel DL, Hopkins HH (1957) Life history of saltcedar. Trans Kans Acad Sci 60:360-369

Mitsch WJ, Gosselink JG (1993) Wetlands, 2nd edn. John Wiley, New York, NY

> Molina JA, Casermeiro MA, Moreno PS (2003) Vegetation composition and soil salinity in a Spanish Mediterranean coastal ecosystem. Phytocoenologia 33:475-494

Morin PJ (1999) Community ecology. Blackwell Science, London

> Mota JF, Peñas J, Castro H, Cabello J, Guirado JS (1996) Agricultural development vs. biodiversity conservation: the Mediterranean semiarid vegetation in El Ejido (Almería, southeastern Spain). Biodivers Conserv 5: 1597-1617

Mouquet N, Loreau M (2003) Community patterns in source-sink metacommunities. Am Nat 162:544-557

Paracuellos M (2006a) How can habitat selection affect the use of a wetland complex by waterbirds? Biodivers Conserv 15:4569-4582

Paracuellos M (2006b) Los humedales como islas de agua en un mar de tierra: la biogeografía y ecología insulares, una vez más al servicio de la conservación. In: Ballesteros GA, Pérez Ruzafa A (eds) Contrastes naturales en la región bioclimática del Mediterráneo. Museo de la Ciencia y el Agua (Ayuntamiento de Murcia), Murcia,

Editorial responsibility: Brant Touchette,

Elon, North Carolina, USA p 175-189

Paracuellos M (2006c) Relationships of songbird occupation with habitat configuration and bird abundance in patchy reed beds. Ardea 94:87-98

Paracuellos M (2008) Effects of long-term habitat fragmentation on a wetland bird community. Revue d'Ecologie (Terre et Vie) 63:227-238

Paracuellos M, Tellería JL (2004) Factors affecting the distribution of a waterbird community: the role of habitat configuration and bird abundance. Waterbirds 27:446-453

Parris KM (2006) Urban amphibian assemblages as metacommunities. J Anim Ecol 75:757-764

Patterson BD, Atmar W (2000) Analyzing species composition in fragments. Bonn Zool Monogr 46:9-24

> Patterson BD, Pacheco V, Solari S (1996) Distributions of bats along an elevational gradient in the Andes of southeastern Peru. J Zool (Lond) 240:637-658

> Pennings SC, Silliman BR (2005) Linking biogeography and community ecology: latitudinal variation in plantherbivore interaction strength. Ecology 86:2310-2319

Petit S, Griffiths L, Smart SS, Smith GM, Stuart RC, Wright RM (2004) Effects of area and isolation of woodland patches on herbaceous plant species richness across Great Britain. Landscape Ecol 19:463-471

Prodon R (1992) Animal communities and vegetation dynamics: measuring and modelling animal community dynamics along forest successions. In: Teller A, Mathy $\mathrm{P}$, Jeffers JRF (eds) Responses to forest ecosystems to environmental changes. Elsevier Applied Science, London, p 126-141

Sánchez-Zapata JA, Anadón JD, Carrete M, Giménez A, Navarro J, Villacorta C, Botella F (2005) Breeding waterbirds in relation to artificial pond attributes: implications for the design of irrigation facilities. Biodivers Conserv 14:1627-1639

Schouten MA, Verweij PA, Barendregt A, Kleukers RJM, de Ruiter PC (2007) Nested assemblages of Orthoptera species in the Netherlands: the importance of habitat features and life-history traits. J Biogeogr 34:1938-1946

> Sebastián-González E, Sánchez-Zapata JA, Botella F (2010) Agricultural ponds as alternative habitat for waterbirds: spatial and temporal patterns of abundance and management strategies. Eur J Wildl Res 56:11-20

Serrano L, Esquivias-Segura MP, Zunzunegui M (2008) Long-term hydrological changes over a seventeen-year period in temporary ponds of the Doñana NP (SW Spain). Limnetica 27:65-78

SPSS (2011) SPSS advanced statistics 20.0. Chicago, IL

> Tanaka N, Asaeda T, Hasegawa A, Tanimoto K (2004) Modelling of the long-term competition between Typha angustifolia and Typha latifolia in shallow water: effects of eutrophication, latitude and initial advantage of belowground organs. Aquat Bot 79:295-310

Ter Braak CJF, Šmilauer P (1998) CANOCO reference manual and user's guide to CANOCO for Windows: software for canonical community ordination (version 4). Microcomputer Power, Ithaca, NY

- Wethered R, Lawes MJ (2005) Nestedness of bird assemblages in fragmented Afromontane forest: the effect of plantation forestry in the matrix. Biol Conserv 123: 125-137

Submitted: November 17, 2011; Accepted: June 22, 2012

Proofs received from author(s): August 22, 2012 